DOI: 10.31866/2617-2674.3.2.2020.217644

UDC 791.633-051:378(477)

\title{
VICTOR KISIN'S PEDAGOGICAL CONCEPT AS A COMPONENT OF MEDIA EDUCATION IN UKRAINE
}

\section{Oleksandr Bezruchko ${ }^{1 \mathrm{a}}$, Olha Fedorovych ${ }^{2 a}$}

${ }^{1}$ Doctor of Study of Art, PhD in Cinematographic Art, Television, Professor; e-mail: oleksandr_bezruchko@ukr.net; ORCID: 0000-0001-8360-9388

${ }_{2}^{2}$ Master's Degree Student, Cinema and Television Arts Department; e-mail: 818for@gmail.com; ORCID 0000-0002-7104-9421

${ }^{a}$ Kyiv National University of Culture and Arts, Kyiv, Ukraine

\section{Keywords:}

cinema;

television;

television school; pedagogical activity; director;

Victor Kisin

\section{For citation:}

\begin{abstract}
The purpose of this research is to analyze Viktor Borysovych Kisin's influence on the formation of a new pedagogical concept in media education in Ukraine. Describe the main aspects of the director's teaching activities. To analyze and systematize V.Kisin's materials about creative innovation, which became the basis for training professionals in the field of audiovisual art. The methodology of the research is applied by the following methods: theoretical - the analysis of V.B. Kisin's theoretical research, the biographical study of the main stages of the director's teaching activity, the generalization of the influence of V.B. Kisin's film pedagogical concepts for the development of the Ukrainian media school. The scientific novelty lies in the fact that various aspects of Viktor Kisin's teaching activity have been comprehensively studied. The specifics of the director's innovative research are outlined and his theoretical research is analyzed. Conclusions. According to the purpose of the research, various aspects of Viktor Borysovych Kisin's pedagogical activity and theoretical research in the field of Ukrainian theatre, cinema and television were analyzed. During the analysis of the research topic and the scientific and memoir publications of Ukrainian scientists, teachers and artists were analyzed, a large number of newspaper and magazine material related to $V$. Kisin's pedagogical and creative activity, as well as his colleagues and students were reviewed, and Kisin's "foreign" period of media pedagogical activity at the Higher School of Television Arts in Hilverson (Netherlands) was also deepened.
\end{abstract}

Bezruchko, O. and Fedorovych, O. (2020). Victor Kisin's pedagogical concept as a component of media education in Ukraine. Bulletin of Kyiv National University of Culture and Arts. Series in Audiovisual Arts and Production, 3(2), pp.205-212.

\section{Problem Statement}

At the beginning of the XXI century, cinematographic and television spheres have been developing at an extremely fast pace in Ukraine and in the world, which requires skilled workers in these fields. The Ukrainian leading universities of the 
corresponding profile are engaged in the preparation of such staff. In addition to the state form of ownership in our country, there are various private schools that also train specialists in the screen arts.

It is worth noting that the first issues of media professionals were prepared at the Kyiv National University of Theater, Film and Television named after I.K. KarpenkoKariy before now it was Kyiv State Theater Institute named after I.K. Karpenko-Kariy (KSUTA was named after Karpenko-Kariy). Later, at Kyiv National University of Film and Television, before now Kyiv State Institute of Culture named after Korniychuk (KSIC was named after O. E. Korniychuk), it was organized a department, where future employees of the cinematographic and television spheres of activity were begun to prepare.

Most of educational programmes and methods are based on the experience of leading experts in the field of audiovisual art nowadays. One of the founders of the national school of audiovisual art is a prominent Ukrainian theatre and television director, art teacher, candidate of art history (1981), Honored Artist of Ukraine (1993) Viktor Borisovich Kisin (April 4, 1933, Khabarovsk, Russia - September 4, 1997, Kyiv, Ukraine), but his pedagogical activity has not been studied enough.

\section{Recent research and publications analysis}

L.Naumova independently and in coauthorship with $\mathrm{O}$. Budnikova identified the features of V. Kisin's television school, and V.Viter thoroughly described the specifics of the educational process of Kisin's creative workshop. The beginning of V. Kisin's pedagogical activity was described by $\mathrm{O}$. Bezruchko, in his scientific research having analyzed the first years of the artist's work with students. Sources on media education published in Ukraine were also used, in which the highlighted information is related to the topic of the scientific article.

\section{Purpose of the article}

The purpose of the research was to analyze the influence of V.B. Kisin on the formation of a new pedagogical concept in media education. Describe the main aspects of the director's teaching activities. Analyze and systematize the materials of V. Kisin's creative innovation, which became the basis for training professionals in the field of audiovisual art.

\section{Main research material}

In the second volume of the collective monograph "V.B. Kisin: is a director, a scientist, a teacher", a co-author of the publication, O. Bezruchko researched V. Kisin's formation as a director and art teacher. In the section "The first period of V.B. Kisin's film pedagogical activity" the first steps of the artist in the field of training specialists in creative specialties were described.

In the 70s of the twentieth century, V. Kisin became one of the teachers of KSUTA named after I.K. Karpenko-Kariy. The director approached artistic pedagogical activity with the special responsibility. Thus, in particular, having realized that only his knowledge and experience would not be enough to train professional specialists, he resorted to various experiments, invited specialists from different fields of art to conduct master classes for students. Hence, V. Kisin understood that students need to be developed comprehensively, because there were 
different areas of directing, and there were many professions related to directing. The master did everything possible to ensure that his students surpassed their teacher (Bezruchko, 2017, p.5).

At the same time during the first years of pedagogical activity, the master studied together with the students. Since the director's experience was purely theatrical, and he trained specialists in the art of television, he needed practice in the screen arts to improve his professional level. That is why Kisin addressed to the vice-principal of KSUTA named after I.K. Karpenko-Kariy with a request to allow using the equipment and materials in volume, which was given off for each student of the Faculty of Film and Television. In this way, he showed his students an invaluable example of the constant desire for perfection, the desire to learn something new and master modern technologies (Bezruchko, 2017, p.9).

In parallel with his media pedagogical activity, V. Kisin was also engaged in scientific work in the field of training specialists in the creative area. In 1980, the director successfully defended his dissertation research "Reincarnation and life experience of the actor" and highlighted his own work in scientific articles: "It should be noted that V.B. Kisin's research was implemented in the books "Directing as an art and profession" and "Life. Actor. Image", and to this day they have been remaining extremely useful both for the practical work of screen art professionals and for the educational process in film schools" (Bezruchko, 2017, p.13).

In the section "The first period of V.B. Kisin's film pedagogical activity", the filming of the four-episode TV series "The Last Proof of Kings" is described in detail, the work began in 1983 and lasted for three years: "The filming went hard, because the film was under meticulous control by the highest party leadership, what was led to politically appropriate screenplay changes. There was a period when V. Kisin had to take a creative vacation at KSITA to shoot in three shifts" (Bezruchko, 2017, p.26).

Judging by the above-mentioned, it can be summarized that the work on the film "The Last Proof of Kings" took a lot of time from V. Kisin. But despite his busy creative schedule, he never forgot about the students, always found time to communicate with them.

It should be mentioned, that extremely interesting for our study is the publication of O.O. Budnikova and L.M. Naumova "Victor Kisin's Dutch direction". Judging by the above-mentioned material, not only V. Kisin went to the Netherlands, but also students of his workshop visited the universities of this country on an exchange program: "In the Netherlands, three groups of Ukrainian students were admitted with their full technical support. Each time Gilversum was the initiator and sponsor of the trips. Dutch groups of students and teachers also visited Ukraine many times. The necessary furniture was sent from Holland: for the needs of the Department of Television Directing and to ensure the educational process in the classrooms. There are still Dutch paper cabinets at the department..." (Budnikova and Naumova, 2017 , p.32). Thus, we can conclude that such an experience has had a positive effect on both students and teachers. It was a great opportunity to compare two different television schools for directing.

In the third volume of the collective monograph "V. B. Kisin: director, scientist, teacher" in the section entitled: "The second period of V. B. Kisin's film pedagogical activity" as one of the important aspects of V. Kisin's media pedagogical activity 
was continued to be studied. Analyzing this section, it can be noted with confidence that in 1986 he headed the Department of Television Directing at KSUTA named after I.K. Karpenko-Kariy, V. Kisin always cared about the teaching staff of the department, gave the opportunity to develop young artists to discover new abilities and talents. That is why many graduates of the university thanks to Kisin's initiative in the future became not only directors but also teachers and scientists: "Among the teachers of the department were not only students M. P. Verhatsky - V. B. Kisin, V.G. Gorpenko, M.I. Merzlikin, V.P. Viter (who studied in the acting studio of Mykhailo Verkhatsky, and then in the directing studio of Viktor Kisin), but also students of Kisin's his longtime friend V.L. Chubasov I.K.Dniprenko" (Bezruchko, 2018, p.11).

Having published her own work in the section "Some principles of V. B. Kisin's theoretical research", L. Naumova (2018, p.139) describes the theoretical research of the director in the third volume of the collective monograph "V.B. Kisin; director, scientist, teacher". The study of the actor's reincarnation and life experience (according to the dissertation)", in particular, having noted that V. Kisin explored many components of creative pedagogy I his dissertation, on which no one had previously paid attention. Thus, having analyzed the material of L. Naumova, it should be emphasized that $\mathrm{V}$. Kisin gave a classification of types of life experience. It is approved by the author's words: "The ontogenesis of the ability to reincarnate and identified the age, especially prone to career guidance in acting was also examined by him. For the first time, the basic principles of the school of activity psychology were involved in the analysis of the actor's creative process and the ability to reincarnate, in the dissertation of V.B. Kisin. The author discerned the combination of data from the theory of the actor's skill and directing with the achievements of psychological science according to that period as an important methodological research direction". (Naumova, 2018, p.139).

It should be noted that the basis for the research of the above topic was the director's own creative and film-pedagogical experience. It was found that he singled out the following concepts: experience, reincarnation, copying, imitation, imitation, and so on. All these terms are part of both directing and acting. This allows us to say that the dissertation fully outlined and summarized various aspects of the master's pedagogical activities.

The specifics of V. B. Kisin's pedagogical activity, its features and differences from other schools L. Naumova described in the section "Some individual principles of V. B. Kisin's theoretical research. School pedagogical method "of the fourth volume of the collective monograph" V. B. Kisin: director, scientist, teacher." Having analyzed the activities of the director, it can be noted that a special television school of Viktor Borysovych Kisin was established in the field of training future specialists in audiovisual art.

The main element, which the director's creative pedagogy was based, was the concept of spectacle. As L. Naumov (2019, p.160) points out: "The director's school, which included such natives of Mykhailo Verkhatskyi's studio as Mykola Merzlikin and Viktor Kisin, was based on understanding the unity of the performing arts of both the performing and screen performing arts. The laws of directing in the interpretation of the representatives of this School were the universal laws of 
the creation of the spectacle. The only difference was in the instruments, in the somewhat peculiar means of expression of different types of performing arts".

It should be noted that V. Kisin was also able to combine skillfully directing and creative pedagogical activities. His school differs from others by a special thoroughness. The master understood that in order to concentrate student's attention, all subjects had to be combined into one subject, so that lectures from different subjects would outline the same period. It made it possible to present the information systematically and thoroughly. As a result, the assimilation of new material was much faster, and perception and awareness were more efficient.

Victor Kisin believed that directing is a too difficult profession because he had no right to show ordinary human weaknesses: he couldn't be late or ill, he had no right to treat others superficially, etc. The director should always keep himself in shape and never complain about a bad mood. This is exactly what $\mathrm{V}$. Kisin tried to convey to his students. And he did it successfully. $\mathrm{He}$ made his students the true professionals and stress-resistant, endured individuals.

One of the V. Kisin's students, V. Viter in the section "Victor Kisin: on the way to the spectacle" the second volume of the collective monograph "V. B. Kissin: director, scientist, educator" noted that V. Kisin was invited to give a course of lectures on film and television directing at the Higher School of Television Arts in Hilverson, he interested foreign students immediately in his own teaching style:

"Students were mostly Dutch and the Danes. The teacher from Ukraine was so popular among the students that after his lectures, they followed him around the school in a herd and, they didn't want to part, absorbing the information they received with admiration. And they, even more, admired the man from whom this information came" (Viter, 2017, p.41).

Foreign students were attracted by the encyclopedic knowledge of the Ukrainian director-teacher. In the section "Some principles of V. B. Kisin's theoretical research. The concept of spectacle" the first volume of the collective monograph "V. B. Kisin: director, scientist, teacher" L. Naumova (2016, p.127) notes: "The range of V. B. Kisin's scientific interests extend from the specifics of acting skills and mechanisms of actor's education to the peculiarities of video as a new screen work of art, to the general principles of the theory of directing and the theory and history of spectacles in general."

"On V. B. Kisin's initiative in the early 80's of the twentieth century, the department of video production was created on Ukrainian television, and later- an association within the structure of the Ukrtelefilm studio. V. Kisin's students worked in it - young directors, the first graduates of the Department of Television Directing founded by him" (Viter, 2017, p.51). It gave young students the opportunity to approve their skills in practice.

Among the V. B. Kisin's graduates there are many famous figures, including the winner of the Taras Shevchenko National Prize of Ukraine I. Kobrin, and the winner of the State Prize of Ukraine named after O. Dovzhenko N. Andriichenko, Honored People's Artists, Chief Directors and CEOs of TV companies and TV channels, just actors who work in Ukraine and abroad.

\section{Conclusions}

According to the aim of the research, various aspects of Victor Kisin's pedagogical activity and theoretical 
prospection in the field of Ukrainian theatre, cinema and television, creative innovation of the artist, which became the basis of the Ukrainian school for training professionals in audiovisual art and production.

During the research the scientific and memoir publications of Ukrainian scientists, teachers and artists were analyzed, a lot of newspaper and magazine material related to V. Kisin's pedagogical and creative activity, his colleagues and students were reviewed, and the "foreign" period of V. Kisin's media pedagogical activity at the Higher School of Television Arts in Hilverson was deepened (the Netherlands).

During his long creative pedagogical activity, Viktor Borysovych Kisin prepared several workshops for directors who now is not only working in television and film production but also educating the young generation of future screen art professionals.

\section{REFERENCES}

Bezruchko, O.V., 2017. Pershyi period kinopedahohichnoi diialnosti V.B. Kisina [The first period of film pedagogical activity V.B. Kisin]. In: V.B. Kisin: rezhyser, naukovets, pedahoh [V.B. Kisin: director, scientist, teacher]. Kyiv: Vydavnychyi tsentr KNUKiM. Volume 2, pp. 5-30.

Bezruchko, O.V., 2018. Druhyi period kinopedahohichnoi diialnosti V. B. Kisina [The second period of film pedagogical activity of V.B. Kisin]. In: V.B. Kisin: rezhyser, naukovets, pedahoh [V.B. Kisin: director, scientist, teacher]. Kyiv: Vydavnychyi tsentr KNUKiM. Volume 3, pp.4-20.

Budnykova, O.O. and Naumova, L.M., 2017. Hollandska rezhysura Viktora Kisina [Dutch direction by Victor Kisin]. In: V.B. Kisin: rezhyser, naukovets, pedahoh [V.B. Kisin: director, scientist, teacher]. Kyiv: Vydavnychyi tsentr KNUKiM. Volume 2, pp.31-35.

Viter, V.P., 2017. Viktor Kisin: na shliakhu do vydovyshcha [Victor Kisin: on the way to the spectacle]. In: V.B. Kisin: rezhyser, naukovets, pedahoh [V.B. Kisin: director, scientist, teacher]. Kyiv: Vydavnychyi tsentr KNUKiM. Volume 2, pp.41-56.

Naumova, L.M., 2016. Okremi polozhennia teoretychnykh poshukiv V.B. Kisina. Poniattia vydovyshcha [Some provisions of theoretical research V.B. Kisin. The concept of spectacle]. In: V.B. Kisin: rezhyser, naukovets, pedahoh [V.B. Kisin: director, scientist, teacher]. Kyiv: Vydavnychyi tsentr KNUKiM. Volume 1, pp.127-141.

Naumova, L.M., 2018. Okremi polozhennia teoretychnykh poshukiv V.B. Kisina. Vyvchennia perevtilennia $i$ zhyttievoho dosvidu aktora (za materialamy dysertatsii) [Some provisions of theoretical research V.B. Kisin. Study of the reincarnation and life experience of the actor (according to the dissertation)]. In: V.B. Kisin: rezhyser, naukovets, pedahoh [V.B. Kisin: director, scientist, teacher]. Kyiv: Vydavnychyi tsentr KNUKiM. Volume 3, pp.138-151.

Naumova, L.M., 2019. Okremi polozhennia teoretychnykh poshukiv V.B. Kisina. Shkola Pedahohichnyi metod [Some provisions of theoretical research V.B. Kisin. School - Pedagogical method]. In: V.B. Kisin: rezhyser, naukovets, pedahoh [V.B. Kisin: director, scientist, teacher]. Kyiv: Vydavnychyi tsentr KNUKiM. Volume 4, pp.160-169. 


\section{ПЕДАГОГІЧНА КОНЦЕПЦІЯ ВІКТОРА КІСІНА ЯК СКЛАДНИК МЕДІЙНОЇ ОСВІТИ УКРАЇНИ}

\section{Олександр Безручкоa, Ольга Федорович²a}

${ }^{1}$ доктор мистецтвознавства, професор;

e-mail: oleksandr_bezruchko@ukr.net; ORCID: 0000-0001-8360-9388

${ }^{2}$ магістрант кафедри кіно-, телемистецтва;

e-mail: 818for@gmail.com; ORCID 0000-0002-7104-9421

а Київський національний університет культури і мистецтв, Київ, Україна

\section{Анотація}

Мета дослідження - проаналізувати вплив Віктора Борисовича Кісіна на формування нової педагогічної концепції у медійній освіті України. Схарактеризувати основні аспекти викладацької діяльності режисера. Проаналізувати та систематизувати матеріали творчого новаторства В. Кісіна, що стали основою для підготовки професійних фахівців в галузі аудіовізуального мистецтва. Методологія дослідження полягає у застосуванні таких методів: теоретичного - аналізу теоретичних пошуків В. Б. Кісіна, біографічного дослідження основних етапів викладацької діяльності режисера, узагальнення впливу кінопедагогічної концепції В. Б. Кісіна на розвиток української медійної школи. Наукова новизна: усебічно досліджено різноманітні аспекти викладацької діяльності Віктора Борисовича Кісіна. Окреслено специфіку новаторських пошуків режисера та проаналізовано його теоретичні дослідження. Висновки. Відповідно до поставленої мети дослідження було проаналізовано різноманітні аспекти педагогічної діяльності та теоретичних пошуків Віктора Борисовича Кісіна на теренах українського театру, кінематографу й телебачення. Під час дослідження теми було проаналізовано наукові та мемуарні публікації українських науковців, педагогів та митців, переглянуто газетні та журнальні матеріали, пов'язані з педагогічною і творчою діяльністю В. Кісіна, його колег та учнів, а також поглиблено вивчено «закордонний» період медіапедагогічної діяльності режисера у Вищій школі телевізійних мистецтв у м. Хілверсан (Нідерланди).

Ключові слова: кінематограф; телебачення; телевізійна школа; педагогічна діяльність; режисер; Віктор Кісін 


\title{
ПЕДАГОГИЧЕСКАЯ КОНЦЕПЦИЯ ВИКТОРА КИСИНА КАК СОСТАВЛЯЮЩАЯ МЕДИЙНОГО ОБРАЗОВАНИЯ УКРАИНЫ
}

\author{
Александр Безручкоa, Ольга Федорович2а \\ ${ }^{1}$ доктор искусствоведения, профессор; \\ e-mail: oleksandr_bezruchko@ukr.net; ORCID: 0000-0001-8360-9388 \\ ${ }^{2}$ магистрант кафедры кино-, телеискусства; \\ e-mail: 818for@gmail.com; ORCID 0000-0002-7104-9421 \\ а Киевский национальный университет культуры и искусств, Киев, Украина
}

\begin{abstract}
Аннотация
Цель исследования - проанализировать влияние Виктора Борисовича Кисина на формирование новой педагогической концепции в медийном образовании Украины. Охарактеризовать основные аспекты преподавательской деятельности режиссера. Проанализировать и систематизировать материалы творческого новаторства В.Кисина, которые стали основой для подготовки профессиональных специалистов в области аудиовизуального искусства. Методология исследования заключается в применении таких методов: теоретического - анализа теоретических изысканий В.Б. Кисина, биографического исследования основных этапов преподавательской деятельности режиссера, обобщение влияния кинопедагогической концепций В.Б. Кисина на развитие украинской медийной школы. Научная новизна: всесторонне исследованы различные аспекты преподавательской деятельности Виктора Борисовича Кисина. Определено специфику новаторских поисков режиссера и проанализированы его теоретические исследования. Выводы. Согласно поставленной цели исследования были проанализированы различные аспекты педагогической деятельности и теоретических изысканий Виктора Борисовича Кисина на территории украинского театра, кинематографа и телевидения. В ходе исследования темы были проанализированы научные и мемуарные публикации украинских ученых, педагогов и художников, пересмотрено газетные и журнальные материалы, связанные с педагогической и творческой деятельностью В. Кисина, его коллег и учеников, а также углубленно изучено «заграничный» период медиапедагогической деятельности режиссера в Высшей школе телевизионных искусств в г. Хилверсан (Нидерланды).
\end{abstract}

Ключевые слова: кинематограф; телевидение; телевизионная школа; педагогическая деятельность; режиссер; Виктор Кисин 